\title{
MENINGKATKAN MUTU PEMBELAJARAN MENULIS ARGUMENTASI DI SEKOLAH DASAR KELAS V LABORATORIUM UNDIKSHA BERDASARKAN PENDEKATAN KONTEKS DAN PROSES BERMEDIAKAN GAMBAR
}

\author{
I Wayan Wendra ${ }^{1}$, I Made Sutama ${ }^{2}$, Putu Triyasa ${ }^{3}$ \\ ${ }^{1,2}$ Jurusan Pendidikan Bahasa dan Sastra Indonesia, Fakultas Bahasa dan Seni, Universitas \\ Pendidikan Ganesha, Singaraja, Indonesia \\ ${ }^{3}$ SD Laboratorium Universitas Pendidikan Ganesha, Singaraja, Indonesia
}

\begin{abstract}
Abstrak
Penelitian ini bertujuan untuk mengetahui penerapan pembelajaran menulis argumentasi di sekolah dasar kelas $\mathrm{V}$ Laboratorium Undiksha berdasarkan pendekatan konteks dan proses bermediakan gambar dapat: (1) meningkatkan aktivitas siswa dalam pembelajaran, (2) meningkatkan hasil belajar menulis argumentasi, dan (3) dapat mengetahui respon siswa terhadap penerapan pembelajaran tersebut. Rancangan penelitian ini adalah penelitian tindakan kelas yang dilakukan dua siklus. Penelitian dilakukan di kelas Vb SD Lab. Undiksha. Data penelitian dikumpulkan melalui observasi, tugas menulis argumentasi,, dan wawancara serta angket. Teknik analisis datanya adalah deskriptif kualitatif( untuk data masalah 1) dan deskriptif kuantitatif(untuk masalah 2 dan 3). Hasil penelitian menunjukkan bahwa penerapan pembelajaran menulis argumentasi berdasarkan pendekatan konteks dan proses bermediakan gambar dapat meningkatkan aktivitas siswa yakni sebelumnya pembelajaran berpusat pada guru, setelah tindakan pembelajaran berpusat pada siswa. Hasil belajar menulis argumentasi siswa juga meningkat yakni sebelumnya hasil belajarnya berkategori cukup, setelah tindakan berkategori baik, serta seluruh siswa merespon positif terhadap pelaksanaan pembelajaran tersebut.
\end{abstract}

Kata kunci: Mutu pemelajaran menulis argumentasi, pendekatan konteks, proses 


\begin{abstract}
The study aimed at finding out whether the implementation of argumentative writing instruction at Laboratory Elementary School Class V Undiksha based on context and process pictures mediated approaches could: (1) improve the students activities in the instructional process, (2) improve the students achievement in writing argumentative text, and (3) figure out the students responses towards the implementations of the instructional model. It was a classroom-based action research conducted at the Lab-Elementary School Undiksha class $\mathrm{V}$ in two different cycles. The data were collected by using observation, writing argumentative text assignment, and interview as well as questionnaires. The data were analyzed descriptive qualitatively(for data of problems 1), and descriptive quantitatively (for data of problems 2 and 3 ). The results indicated that the implantation of writing instructional model in argumentative text based on context and process pictures mediated approaches could improve the students the studens activities, that was before the action, the instructional activity was minly teacher centered, however, after the action the instructional activity was directing to students centered. The students achievement in writing before the action was in "moderate" category, while after the action improving into "good" category, in addition all students provided positive responses towards the implementation of the model.
\end{abstract}

Keywords: instructional quality in argumentative writing, context and process approaches

\section{PENDAHULUAN}

Walaupun keterampilan menulis telah diajarkan sejak lama dengan berbagai macam pendekatan, hasil pengajaran yang diharapkan belum dapat dicapai(Sutama,2010:1). Dijelaskan lebih lanjut, yang lebih parah lagi adalah pengajar pun enggan melaksanakan pembelajaran menulis. Keengganan ini salah satu faktor penyebabnya adalah ketidakmampuan pengajar sendiri dalam menulis. Ini menjadikannya tidak tahu jelas bagaimana semestinya menulis diajarkan, kecuali memberikan teori kepada pembelajar(Sutama,2010).

Hasil survei ke lapangan menunjukkan bahwa kondisi prestasi belajar menulis siswa SD kelas $\mathrm{V}$ Laboratorium Undiksha belum memadai yakni belum mencapai standar yang ditetapkan yakni rata-rata 70 . Apalagi dalam menulis argumentasi yang menuntut pemikiran yang lebih rumit dan jelimet. Hal ini dutunjukkan dari hasil pembelajaran menulis yang telah dilakukan selama ini. Sebagaimana yang telah dikemukakan oleh guru, bahwa upaya pembelajaran yang selama ini telah dilaksanakan adalah melalui menjelaskan teori menulis argumentasi berdasarkan contoh yang sudah ada, kemudian siswa ditugaskan membuat tulisan argumentasi sesuai dengan minat atau kesukaannya. Pembelajaran menulis tersebut hasilnya sebagai berikut. Dari jumlah 40 siswa nilai rata-rata kelasnya hanya 6,02 tergolong cukup, dan ada 4 siswa(10\%) yang tergolong gagal atau tidak lulus kalau dilihat dari batas kelulusan. Rincian lebih jauh adalah sebagai berikut: 12 orang (30\%) memperoleh nilai baik, 24 siswa(60\%) tergolong cukup, 4 siswa(10\%) tergolong kurang(Hasil wawancara dengan guru bahasa Indonesia kelas $\mathrm{V}$ SD Lab. Undiksha).

Cara lain yang juga pernah dilakukan sebagai alternatif adalah dengan 
memanfaatkan apa yang ada di sekitar lingkungan siswa karena tema bahasannya adalah memanfaatkan barang-barang bekas di lingkungan siswa. Pada awalnya agar siswa memiliki konsep, guru menjelaskan berdasarkan contoh tulisan yang sudah ada tentang argumentasi memanfaatkan barang bekas/sampah, kemudian siswa ditugaskan melihat secara langsung barang bekas/sampah di lingkungannya sendiri dengan pertimbangan karena masing anak memiliki lingkungan yang berbeda. Selanjutnya siswa diajarkan berargumentasi dengan ditugaskan menulis argumentasi. Adapun hasilnya adalah sebagai berikut. Nilai rata-rata kelas siwa adalah 6,39 masih tergolong cukup belum mencapai standar yang dinginkan. Ada 2 orang siswa (5\%) yang masih gagal dalam upaya meraih prestasi belajarnya. Rincian hasil secara rinci adalah sebagai berikut. Ada 5 siswa $(12,5 \%)$ hasilnya sangat baik, 14 siswa (35\%) tergolong baik, 19 siswa (47,5\%) tergolong cukup, dan 2 siswa (5\%) tergolong kurang atau gagal (Hasil wawancara dengan guru bahasa Indonesia kelas $\mathrm{V}$ Lab. Undiksha).

Di sisi lain, berdasarkan wawancara dengan beberapa siswa sebagai sampel terkait dengan hasil belajar yang diperoleh tersebut bahwa kesulitan yang dialami adalah mereka walaupun sudah mendapat penjelasan teori menulis dari guru juga sulit mengerti penjelasan guru dan tidak mengerti tulisan yang harus dibuat serta untuk apa dan sulit mengembangkannya menjadi tulisan yang sesuai dengan permintaan guru. Akibat dari kesulitan-kesulitan tersebut membuat mereka kurang senang saat pembelajaran menulis. Dari ungkapan tersebut, kalau diidentifikasi kesulitan siswa adalah pertama dalam hal mengertikan penjelasan teori menulis yang diberikan guru, kedua dalam hal tulisan yang bagaimana yang harus dikerjakan, dan ketiga tidak mengerti yaitu untuk apa membuat tulisan tersebut dan cara mengembangkan tulisan. Seluruh kesulitan tersebut mengakibatkan siswa kurang menyenangi pelajaran menulis.

Upaya yang dilakukan guru dalam pembelajaran menulis di sekolah yang telah disurvei cenderung hanya melalui pemberian penjelasan teori menulis, kemudian guru menugaskan siswa menulis dengan topik bebas atau ditentukan, dan akhirnya guru menilai hasil tulisan siswa.

Cara yang ditempuh oleh guru tersebut masih berorientasi produk bukan proses. Upaya tersebut tidak membimbing dan memberi pengalaman kepada siswa secara alamiah untuk menemukan sendiri dan belajar memecahkan masalahnya sendiri karena pola pembelajarannya masih berorientasi lebih banyak pada guru (teacher-oriented) yang semestinya pola pembelajaran diorientasikan pada siswa (student-oriented). Kelas masih berfokus pada guru sebagai sumber utama pengetahuan sehingga kurang memberdayakan siswa yaitu mendorong siswa mengkonstruksikan pengetahuan di benak mereka sendiri. Guru menjelaskan dengan ceramah walaupun dengan contoh mengharuskan siswa menghafal fakta-fakta sehingga siswa dalam proses belajar tidak mengalami secara alamiah. Oleh karena itu, miskonsepsi dan cara keliru yang dilakukan guru selama ini perlu segera dibenahi. Kondisi ini perlu segera diatasi yaitu dengan menemukan langkah-langkah praktis dalam pembelajaran menulis argumentasi.

Setelah berdiskusi antara peneliti dan guru dan menganalisis kurikulum serta didasarkan atas hasil identifikasi masalah yang ada, maka tindakan yang disepakati Jurnal Pendidikan Indonesia | 115 
akan dilakukan adalah pembelajaran menulis di kelas $\mathrm{Vb}$ yaitu menulis argumentasi yang tanpa penjelasan teori menulis yang menyulitkan siswa dengan memanfaatkan media gambar yang dekat dengan lingkungan atau kehidupan siswa dan disukai siswa yakni menerapkan pembelajaran menulis argumentasi di sekolah dasar berdasarkan pendekatan konteks dan proses bermediakan gambar. Diyakini bahwa ini adalah alternatif pemecahan masalah yang dipandang lebih tepat dalam meningkatkan mutu pembelajaran menulis argumentasi di sekolah dasar berdasarkan pendekatan konteks dan proses bermediakan gambar.

Berdasarkan uraian pada bagian pendahuluan di atas, maka rumusan masalah dalam penelitian ini adalah sebagai berikut. (1) Apakah pembelajaran menulis argumentasi berdasarkan pendekatan konteks dan proses bermediakan gambar dapat meningkatkan aktivitas siswa kelas $\mathrm{Vb}$ Lab. Undiksha dalam belajar menulis argumentasi? (2)Apakah pembelajaran menulis argumentasi berdasarkan pendekatan konteks dan proses bermediakan gambar dapat meningkatkan hasil belajar menulis argumentasi siswa SD Lab. Undiksha? (3) Bagaimana respon siswa terhadap pembelajaran menulis argumentasi berdasarkan pendekatan konteks dan proses bermediakan gambar yang telah diterapkan?

Hasil penelitian ini akan memberikan manfaat yang bersifat praktis. Manfaat praktis yang dimaksud terutama bermanfaat bagi pihak-pihak yang terlibat dalam dunia pendidikan, dengan rincian sebagai berikut. (1) Bagi para siswa, penelitian ini akan sangat beramanfaat karena secara tidak langsung mereka terbantu dalam mengikuti pembelajaran menulis argumentasi yang sangat memberi peluang bagi mereka yang kreatif akan dapat meningkatkan hasil belajar secara lebih optimal. Hal ini disebabkan oleh pendekatan konteks dan proses yang dapat memberi peluang kreatif, berinteraksi dan berkarya seluas-luasnya dengan temannya yang cukup hiterogen. (2) Bagi guru bahasa Indonesia, temuan penelitian ini dapat membuka wawasan guru dan dapat menjadikan startegi alternatif dalam mengelola pembelajaran menulis berdasarkan pendekaan konteks dan proses sehingga dapat meningkatkan mutu pembelajaran menulis di sekolah. (3) Bagi dosen, hasil penelitian ini akan memberi gambaran kondisi riil pembelajaran menulis di lapangan sehingga dapat mengantisipasi dalam merancang perkuliahan yang sesuai dengan tantangan riil di lapangan bagi para mahasiswa calon guru bahasa Indonesia. (4) Bagi pengambil kebijakan di Depdikbud, temuan penelitian ini dapat dijadikan acuan strategi pembelajaran menulis dalam meningkatkan mutu pembelajaran menulis di Sekolah Dasar.

Tindakan yang ditempuh untuk mengatasi masalah di atas didasarkan atas pemikiran berikut. Temuan-temuan dari psikologi kognitif menyediakan teori dasar untuk memperbaiki pembelajaran secara umum. Premis dasar dalam psikologi kognitif adalah bahwa belajar merupakan proses pengkonstruksian pengetahuan baru berdasarkan pengetahuan yang sudah ada sekarang. Menurut Glaser ( dalam Gijselaers, 1996), belajar merupakan proses konstruktif dan bukan proses penerimaan. Proses kognitif yang disebut metakognisi mempengaruhi penggunaan pengetahuan dan faktor sosial dan kontekstual mempengaruhi pembelajaran. Dengan demikian karakteristik pembelajaran perlu Jurnal Pendidikan Indonesia | 116 
perubahan karena pembelajaran bukanlah sekadar pengisian kepala siswa dengan sejumlah imformasi, dan pikiran siswa bukanlah sebagai kotak kosong yang dapat diisi melalui pengulangan dan latihan semata. Pembelajaran harus dapat memberdayakan siswa untuk terlibat aktif secara fisik dan mental agar siswa terbiasa mandiri, cerdas, kritis dan kreatif menghadapi tantangan kehidupan.

Menurut Dankin dan Biddle (1974) proses pembelajaran merupakan variabel sentral yang berpengaruh secara langsung terhadap hasil belajar. Kualitas pembelajaran dapat dilihat dari segi proses dan hasil. Dari segi proses, pembelajaran yang berkualitas ditunjukkan dengan adanya motivasi peserta didik untuk terlibat secara aktif dalam kegiatan pembelajaran yakni peserta didik senang dan antusias mengikuti kegiatan pembelajaran. Dari segi hasil, kualitas pembelajaran dengan ditunjukkan dengan adanya pencapaian tujuan atau hasil pembelajaran oleh peserta didik.

Kehadiran Kurikulum berbasis kompetensi tentu saja diharapkan dapat membekali peserta didik agar dapat menghadapi tantangan kehidupan secara mandiri, cerdas, kritis, rasional dan kreatif. Pada buku pedoman KBK tahun 2001 dan direvisi tahun 2003 oleh Depdiknas disebutkan ada 5 ciri KBK sebagai berikut: (1) menekankan pada ketercapaian kompetensi siswa, baik secara individual maupun klasikal, (2) berorientasi pada hasil belajar (learning autcomes) dan keragaman, (3) penyampaian dalam pembelajaran menggunakan pendekatan dan metode yang bervariasi, (4) sumber belajar bukan hanya guru tetapi juga sumber belajar lainnya yang memenuhi unsur edukatif, dan (5) penilaiannya menekankan pada proses dan hasil belajar dalam upaya penguasaan atau pencapaian suatu kompetensi (Balitbang Depdiknas, 2001,2002:5). Untuk itu sangat diperlukan upaya pembelajaran yang dapat memenuhi harapan kurikulum tersebut.

Dari uraian tersebut di atas, maka dapatlah ditegaskan bahwa mutu suatu pembelajaran akan dapat dilihat dari segi proses dan dari segi hasil pembelajaran. Dari segi proses, pembelajaran yang bermutu ditunjukkan dengan adanya motivasi peserta didik untuk terlibat secara aktif dalam kegiatan pembelajaran yakni peserta didik senang dan antusias mengikuti kegiatan pembelajaran. Dari segi hasil, kualitas pembelajaran dengan ditunjukkan dengan adanya pencapaian tujuan atau hasil pembelajaran oleh peserta didik. Implementasi kurikulum berbasis kompetensi dengan pendekatan kontektual(contextual teaching learning) mengarah pada upaya meningkatkan mutu pengajaran dan pembelajaran di tingkat pendidikan dasar dan menengah untuk mempersiapkan para peserta didik menghadapi tantangan masa depan. Pendekatan kontekstual diperkenalkan kepada guru adalah konsep belajar yang membantu guru mengaitkan materi-materi yang diajarkannya dengan situasi dunia nyata siswa (Direktorat Jendral Pendidikan Dasar dan Menengah, 2002: iii). Lebih lagi dalam kegiatan menulis karena ada pandangan bahwa menulis adalah aktivitas sosial. Sebagai aktivitas sosial, menulis tidak pernah dilakukan dalam situasi vakum tanpa konteks. Menulis adalah tindak komunikasi, sebagai upaya membagi hasil observasi, inforamasi, pikiran atau ide, dan pengalaman kepada orang lain (Cohen dan Riel, 1989). Hal ini telah didukung oleh hasil penelitian yang telah peneliti lakukan yakni penelitian tentang pembelajaran kontekstual Jurnal Pendidikan Indonesia | 117 
melalui mengobservasi objek otentik dapat meningkatkan mutu(proses dan hasil) pembelajaran menulis deskripsi siswa SMPN4 Singaraja(Wendra,2009). Bahkan hasil penelitian ini telah dipilih oleh Puslit Undiksha untuk disosialisasikan kepada guru-guru SD, SMP,SMA melalui seminar tingkat Provinsi tahun 2010 di Klungkung(Desiminasi Hasil Penelitian Dosen Undiksha oleh Puslit Undiksha,2010).

Dalam kaitannya dengan menulis argumentasi, Winch dkk(2006) menegaskan bahwa wacana argementasi yang cenderung bersifat analitis lebih sulit dipahami oleh anak-anak. Ini adalah tantangan bagi guru untuk dapat memudahkan anak dalam belajar menulis dengan menggunakan alternatif pendekatan serta teknik yang cocok dengan kondisi anak. Sutama(2010) menegaskan bahwa pada jenjang sekolah dasar, pada kelas peralihan dari kelas rendah ke kelas tinggi,pembelajaran menulis wacana mulai diperkenalkan dan ditegaskan bahwa pendekatan yang cocok diterapkan adalah pendekatan konteks. Dikatakan demikian karena pada jenjang ini siswa belum bisa diajak berbicara banyak tentang teori menulis. Pemaksaan memperkenalkan istilah-istilah teknis dalam menulis justru akan semakin membingungkan siswa. Sebaliknya, dengan hanya memberi konteks menulis, terutama tujuan menulis, seperti menceritakan, membedakan, atau memberi pendapat tentang sesuatu, siswa pada jenjang itu akan dapat memproduksi tulisan dengan pola yang sesuai. Pendekatan konteks akan dipadukan dengan pendekatan proses. Pendekatan proses akan mengajak siswa dalam situasi menulis proses menulis yang sebenarnya yakni melalui tahapan menulis yang terdiri dari beberapa tahap, yaitu tahap perencanaan,tahap penuangan, dan tahap peninjauan. Penerapan pendekatan ini di dalam pembelajaran menulis adalah siswa dibantu memahami proses menulis dan membangun repertoir strategi pramenulis,menulis, meninjau dan menulis ulang. Lebih lanjut siswa dituntun menjalani proses ini dengan harapan mereka dapat menghasilkan tulisan yang baik. Dengan memadukan pendekatan konteks dan proses dalam belajar menulis argumentasi di sekolah dasar, maka pendekatan konteks akan menghindari penjelasan teori menulis yang bersifat teknis yang menyulitkan dan membingungkan siswa menulis apa dan untuk apa. Pendekatan proses akan menuntun dan membantu siswa dalam proses menulis mulai dari merencanakan dengan mendiskusikan topik, kemudian proses penuangan, lalu peninjauan untuk revisi dan akhirnya menulis ulang. Sedangkan penggunaan gambar yang dekat denga kehidupan siswa dan disukai siswa akan memotivasi siswa untuk belajar menulis Berdasarkan hal itu, pembelajaran menulis argumentasi berdasarkan pendekatan konteks dan proses bermediakan bambar akan dapat meningkatkan mutu pembelajaran menulis argumentasi di sekolah dasar.

Dari uraian tersebut di atas, maka dapatlah ditegaskan bahwa mutu suatu pembelajaran akan dapat dilihat dari segi proses dan dari segi hasil pembelajaran. Dari segi proses, pembelajaran yang bermutu ditunjukkan dengan adanya motivasi peserta didik untuk terlibat secara aktif dalam kegiatan pembelajaran yakni peserta didik senang dan antusias mengikuti kegiatan pembelajaran. Dari segi hasil, kualitas pembelajaran dengan ditunjukkan dengan adanya pencapaian tujuan atau hasil pembelajaran oleh peserta didik.

Jurnal Pendidikan Indonesia $\mid 118$ 
Terkait dengan menulis argumentasi, ada pandangan bahwa menulis adalah aktivitas sosial (Hull dalam Sutama, 2010). Lebih lanjut ditegaskan, sebagai aktrivitas sosial, menulis tidak pernah dilakukan dalam situasi vakum. Menulis adalah tindak komunikasi, sebagai upaya membagi hasil observasi, informasi, pikiran atau ide, dan pengalaman kepada orang lain. Argumentasi tidak lain dari usaha untuk mengajukan bukti-bukti atau menentukan kemungkinan-kemungkinan untuk mengetahui sikap atau pendapat mengenai suatu hal. Tulisan argumentasi adalah suatu tulisan yakni penulis berusaha merangkaikan fakta-fakta sedemikian rupa sehingga ia mampu menunjukkan apakah suatu pendapat atau suatu hal tertentu itu benar atau tidak(Keraf, 2004). Tujuannya adalah untuk mempengaruhi sikap dan pendapat orang lain, agar mereka itu percaya dan pada akhirnya sesuai dengan apa yang diinginkan pembicara atau penulis (Keraf,2004:3). Struktur argumentasi secara umum memuat aspek pendahuluan, tesis, alasan/bukti, dan simpulan. Dalam bentuk mini (wacana singkat) sebuah argumentasi dapat berwujud sebuah paragraf yang di dalamnya minimal ada tesis dan alasan. Hal ini senada dengan pendapat Toulmin(1979:33) bahwa pola dasar sebuah argumentasi terdiri atas tesis dan bukti/alasan. Tesis yang dimaksud adalah pernyataan yang menunjukkan sikap penulis terhadap topik tulisan yang akan dibuktikan dalan paparan pendapatnya. Untuk menghasilkan pernyataan tesis, seorang penulis dapat merumuskan pertanyaan yang berkaitan dengan topik tulisan,lalu menjawabnya. Jawaban yang sudah dianggap mantap itulah yang merupakan pernyataan tesis.
Dalam berargumentasi seseorang dapat merangkai fakta-fakta atau bukti-bukti sedemikian rupa sehingga mampu menunjukkan apakah suatu pendapat itu benar atau tidak. Dengan demikian mengajukan argumentasi merupakan kemampuan menyatakan dan menyampaikan fakta-fakta serta bukti-bukti untuk menunjukkan benar tidaknya suatu pendapat melalui penggunaan bahasa.

Bormann(1991:192)

mengemukakan tiga hal yang dapat dihubungkan dengan argumentasi. Ketiga tersebut yaitu (1) argumentasi dapat dihubungkan dengan pokok masalah yang ditampilkan sebagai pertanyaan terhadap kenyataan; (2) argumentasi dapat dihubungkan dengan pertanyaaan mengenai nilai-nilai; (3) argumentasi dapat dihubungkan dengan pertanyaan mengenai kebijakan.

Dalam pembelajaran menulis argumentasi ini, akan dihubungkan dengan butir satu yaitu argumentasi yang dihubungkan dengan pokok masalah. Masalah yang dimaksud adalah hal atau masalah yang dekat dengan kehidupan siswa dan disukai siswa dengan bermediakan gambar. Topik yang ditetapkan dalam pembelajaran menulis argumentasi harus didasarkan oleh sejumlah pertimbangan yang matang. Topik yang ditetapkan hendaknya sesuai dengan tingkat pengajaran dan minat siswa. Menurut Piaget(dalam Santyasa dan Sukadi,2008), usia SD yang masih berada pada tahapan operasi konkret sangat memerlukan objekobjek konkret sebagai pijakan untuk memandu belajarnya. Objek-objek konkret yang ada di lingkungan mereka atau bendabenda artivisial dapat digunakan sebagai fasilitas belajar terpadu. Benda-benda tersebut merupakan objek anak untuk Jurnal Pendidikan Indonesia | 119 
bermain dan merangsang rasa ingin tahunya secara optimal. Rasa ingin tahu yang bangkit melalui proses bermain dapat merangsang mereka untuk mengekpresikan dunia dan membangkitkan kompetensi pemecahan masalah.

Pakar lain mengatakan bahwa topik dengan media gambar adalah penyajian topik yang bersifat non verbal yang dimaksudkan untuk menghindari penjelasan teori oleh guru yang jelimet dan membosankan siswa. Weir (1990:62) mengatakan bahwa keuntungan stimulus nonverbal jika mampu menyajikan menyajikan informasi secara jelas dan tepat, akan memungkinkan siswa untuk tidak berlama-lama menghasilkan tulisan. Tugas menulis dengan menyajikan materi nonverbal akan semakin efektif jika meminta siswa mengomentari kecenderungan tertentu yang tampak dalam grafik, atau membandingkan dan mmpertentangkan sepasang gambar yang berbeda.

Terkait dengan pembelajaran dengan media gambar Wright(1992) mengatakan bahwa gambar dapat memainkan sejumlah peran: (1) Gambar dapat memotivasi murid dan menarik perhatian mereka. (2) Gambar dapat memberikan konteks penggunaan bahasa dan membawa dunua nyata ke dalam kelas. (3) Gambar dapat bercerita sebagaimana adanya, diinterpretasikan, atau dikomentari secara subjektif. (4) Gambar dapat memberikan isyarat tentang jawaban suatu pertanyaan. (5) Gambar dapat memberi stimulus dan informasi untuk diacu dalam bercakap-cakap, berdiskusi dan bercerita. Dengan uraian di atas jelaslah bahwa pembelaran menulis argumentasi akan sangat efektif dengan penyampaian materi dengan bermediakan gambar.
Terkait dengan pendekatan, ada sejumlah pendekatan dalam pembelajaran menulis, yaitu pendekatan konteks, pendekatan proses dan pendekatan pola(Reimes,1991). Pendekatan konteks mengasumsikan bahwa di dalam aktivitas menulis yang sesungguhnya penulis berorientasi pada tujuan menulis dan pembaca yang menjadi sasaran tulisan. Implementasi dari penerapan pendekatan ini di dalam pembelajaran di kelas adalah siswa ditugasi untuk menulis dengan tujuan dan pembaca yang telah dispesifikasi. Lebih lanjut dengan spesifikasi semacam itu, diharapkan siswa dapat menghasilkan tulisan dengan pola retorika yang baik.

Pada jenjang sekolah dasar dimana pembelajaran menulis wacana mulai diperkenalkan, pendekatan konteks cocok diterapkan. Dikatakan demikian karena pada jenjang itu, siswa belum bisa diajak berbicara banyak tentang teori menulis. Pemaksaan memperkenalkan istilah-istilah teknis dalam menulis justru akan semakin membingungkan siswa. Sebaliknya, dengan hanya memberikan konteks menulis, terutama tujuan menulis, seperti meceritakan, membedakan atau memberi pendapat tentang sesuatu, siswa pada jenjang itu akan dapat memproduksi tulisan dengan pola yang sesuai. Leki dkk(2008) menyatakan, "In supprtive,meaning-oriented writing contexts, beginning L2 writers brought with them and were able to draw upon a variety of resources and strategies to succesfully create expresive texts that communicated meaning."

Pendekatan proses di sisi lain mengasumsikan bahwa menulis terdiri atas beberapa tahap, yaitu: tahap perencanaan,tahap penuangan, dan tahap peninjauan. Aktivitas pramenulis, berdiskusi di dalam kelompok menulis, dan mencobaJurnal Pendidikan Indonesia | 120 
coba menulis akan membantu mengembangkan kelancaran menulis, sekaligus mengatasi kemacetan dalam menulis yang diakibatkan oleh keterbatasan memori(Myers dalam Sutama,2010). Penerapan pendekatan ini dalam pembelajaran menulis adalah siswa dibantu memahami proses menulis dan membangun repertoire strategi menulis, menulis, meninjau, dan menulis ulang. Lebih lanjut, siswa dituntut menjalani proses ini dengan harapan mereka dapat menghasilkan tulisan yang baik.

Dengan pendekatan konteks, siswa tidak akan merasa bahwa menulis dilakukan hanya untuk memenuhi tugas dari guru, tetapi akan merasa berkomunikasi untuk mencapai tujuan tertentu dengan pembaca sasaran yang ditetapkan. Dengan pendekatan proses, kekurangan siswa dalam pengetahuan tentang topik yang akan ditulis akan teratasi melalui diskusi pramenulis dibantu media gambar, kelancaran mereka dalam menulis tidak akan terganggu oleh hal-hal yang bersifat gramatikal, dan kerendahan mutu tulisan mereka akan ditingkatkan melalui proses peninjauan atau revisi. Dengan penerapan kedua pendekatan yakni pendekatan konteks dan pendekatan proses yang bermediakan gambar mutu pembelajaran menulis argumentasi akan dapat ditingkatkan.

\section{METODE PENELITIAN}

Penelitian ini tergolong penelitian tindakan kelas. Sesuai dengan sifatnya, penelitian tindakan kelas bersifat siklikal yang dilaksanakan secara multisiklus. Secara garis besarnya, kegiatan setiap siklus meliputi: refleksi awal, perencanaan tindakan, pelaksanaan tindakan, observasi/evaluasi, dan refleksi untuk menentukan rencana tindakan pada siklus berikutnya (Kemmis dan McTaggart, 1998).

Subyek penelitian ini adalah satu kelas yaitu siswa kelas $\mathrm{Vb}$ beserta pelaksana pemberi tindakan di kelas itu yakni guru pengajarnya. Pihak yang dilibatkan dalam penelitian ini ialah dua dosen dan seorang guru kelas Vb SD Lab. Undiksha Singaraja, yang berkolaborasi dalam proses penelitian ini mulai dari perencanaan, pelaksanaan, sampai penyusunan laporan.

Rincian kegiatan memulai siklus 1adalah sebagai berikut. (1) Guru memberikan orientasi materi pelajaran beserta model pembelajaran yang akan diterapkan, sumber yang digunakan, serta penegasan kemampuan yang akan dilatihkan. (2) Siswa dibagi dalam 5 kelompok, dengan cara guru menghitung siswa, satu, dua, tiga, empat, dan lima. Yang nomor satu masuk kelompok satu, yang nomor dua masuk kelompok dua dan seterusnya. (3) Guru bersama siswa menetapkan topik disukai siswa dan membagi gambar benda yang telah disiapkan untuk topik tulisan, kemudian dibagikan juga blangko untuk mencatat hasil pencermatan siswa terhadap gambar. (4) Guru bersama siswa menetapkan tujuan menulis dan sasaran tulisan. (5) Siswa mencermati gambar benda tersebut dan mengidentifikasi kelebihan atau keunggulan yang ada pada benda tersebut dan diungkapkan dalam bentuk kalimat. (6) Setelah 20 menit, secara bergantian masing-masing kelompok ke depan kelas mengemukakan secara lisan hasil observasinya. Setelah itu kelompok lain menanggapinya, boleh bertanya atau memberikan masukan/pendapat yang terkait dengan hasil pendapat temannya dan penataannya sebagai persiapan menulis 
(argumentas)i. (7) Siswa ditugaskan menyusun sebuah paragraf (argumentasi) berdasarkan data yang diperoleh saat mencermati dan berdasarkan hasil penyempurnaan saat diskusi secara klasikal. (8) Guru dengan melibatkan siswa membahas(mengoreksi) hasil kerja siswa yang berupa tulisan (argumentasi) menyangkut kelebihan dan kekurangan tulisan yang sudah dibuat dan merevisinya. (9) Guru menugaskan siswa menulis ulang berdasarkan hasil koreksi dan revisi yang telah dilakukan.

Selama pelaksanaan tindakan, peneliti secara kolaboratif melakukan observasi terhadap keseluruhan pelaksanaan tindakan baik mengobservasi guru maupun siswa.

Peneliti secara kolaboratif bersama guru sebagai anggota peneliti melakukan refleksi. Refleksi dilaksanakan pada setiap akhir pembelajaran yaitu berkenaan dengan kendala dan masalah yang dialami guru maupun siswa, alokasi waktu mengerjakan tugas, hasil belajar, dan respon siswa terhadap pembelajaran yang telah berlangsung. Hasil refleksi tersebut selanjutkan digunakan sebagai dasar untuk menyempurnakan tahapan-tahapan penelitian pada siklus berikutnya.

Data yang diperlukan dalam penelitian ini adalah (1) data tentang aktivitas siswa dalam pembelajaran menulis argumentasi, dikumpulkan dengan metode observasi, (2) data tentang respon siswa terhadap pembelajaran menulis argumentasi, dikumpulkan dengan metode wawancara dan angket, dan (3) data tentang hasil belajar menulis argumentasi dikumpulkan dengan metode penugasan menulis argumentasi. Penerapan masingmasing metode akan dibantu dengan instrumen masing-masing. Semua data tersebut diperlukan untuk melakukan refleksi dan menarik kesimpulan pada setiap akhir siklus.

Kriteria keberhasilan tentang aktivitas siswa, ditunjukkan dengan terjadinya perubahan aktivitas pembelajaran yang dilakukan guru yang semula berpusat pada guru menjadi berpusat pada siswa, dan terajadi perubahan interaksi dari dua arah menjadi multi arah. Kriteria keberhasilan dari respon siswa yakni $80 \%$ dari jumlah siswa merespon positif terhadap pelaksanaan pembelajaran. Kriteria keberhasilan hasil belajar menulis argumentasi ditunjukkan dengan keberhasilan perolehan rata-rata kelas pada kategori baik, atau $80 \%$ dari jumlah siswa memperoleh nilai kategori baik.

Data tentang aktivitas siswa dalam pembelajaran menulis argumentasi dianalisis secara deskriptif kualitatif. Data tentang respos siswa terhadap penerapan pembelajaran dianalisis secara deskriptif kuantitatif. Penilaian alternatif respon terdiri dari sangat tinggi (skor 5), tinggi(skor 4), cukup (skor3), rendah (skor 2), dan sangat rendah(skor 1). Rerata skor respon seluruh siswa dihitung dengan cara jumlah skor seluruh respon siswa dibagi jumlah siswa. Setelah itu akan dikonversikan dengan kriteria respon siswa yang diadaptasi dari model penilaian Nurkancana dan Sunartana(1996). Dengan demikian akan diperoleh gambaran tingkat respon yakni sangat positif, positif, cukup positif,kurang positif, dan sangat kurang positif.

Data tentang hasil belajar menulis argumentasi dianalisis secara deskriptif kuantitatif yaitu tulisan yang dihasilkan siswa diberi skor dengan menggunakan panduan model "Profil Penilaian Karya Tulis" yang diadaptasi dari Jurnal Pendidikan Indonesia | 122 
"ESL Composition Profile" (Jacobs dkk., 1981),baik dari segi isi tulisan yaitu kelengkapan unsur-unsur objek yang harus diargumentasikan maupun organisasi tulisan yaitu sistematika atau keruntutan penjelasan objek. Dengan mengacu pada profil ini, skor maksimal yang bisa dicapai siswa adalah 100 (60 dari komponen isi, dan 40 dari komponen organisasi).

\section{HASIL PENELITIAN DAN PEMBAHASAN}

Diperlukan dua siklus untuk dapat mencapai hasil penelitian ini. Pada siklus 1 media gambar yang digunakan adalah hadiah yang berupa tas sekolah yakni pilih tas ransel dan tas selempang yang memakai tali. Tampak pembelajaran berpusat pada siswa baik saat diskusi kelompok maupun saat diskusi antar kelompok. Interaksi terjadi multi arah yakni dari siswa dengan siswa dalam diskusi kelompok dan antar kelompok juga terjadi interaksi antar siswa dan siswa juga kepada guru sebagai pemandu jalannya diskusi secara klasikal saat diskusi antar kelompok yakni penyajian hasil diskusi kelompok.

Hasil pembelajaran menulis argumentasi skor rata-rata yang diperoleh pada siklus 1 ini adalah 75 tergolong baik. Sejumlah 4 siswa (13\%) memperoleh nilai berkategori sangat baik, sejumlah 19 siswa (63\%) memperoleh nilai berkategori baik, dan 7 siswa (24\%) memperoleh nilai berkategori cukup. Hasil ini yakni penerapan pembelajaran menulis argumentasi berdasarkan pendekatan konteks dan proses bermediakan gambar telah menampakkan peningkatan hasil yang lebih baik dibandingkan dengan skor rata-rata yang diperoleh saat refleksi awal yang hanya pada kategori cukup. Kelemahan tulisan yang masih tampak adalah hanya dari segi bentuk paragraf. Memulai paragraf tidak menjorok kedalam dan rata pinggir kanan dan kiri. Ada kalimat yang dibuat tidak dimulai dengan huruf besar dan diakhiri dengan tanda titik.

Hasil tentang respon siswa diperoleh adalah sebagai berikut. Hampir semua siswa yaitu 95\% dari jumlah siswa dan merespon positif pelaksanaan pembelajaran ini. Mereka merespon positif karena merasa terbantu dan menjadi lebih mudah dalam menghasilkan tulisan. Melalui kegiatan pencermatan gambar untuk melihat keunggulan yang dipilih sebagai bahan alasan atau argumentasi yang diungkap dalam bentuk kalimat, sehingga dalam menulis menjadikan paragraf tinggal menyusun dan menghubungkan saja satu kalimat dengan kalimat lainnya. Adanya kegiatan diskusi kelompok mereka merasa terbantu dalam menemukan ide lebih lengkap sebagai bahan argumentasi dan mereka menjadi lebih yakin lagi atas temuannya melalui diskusi antar kelompok melalui penyajian hasil di depan kelas. Ada beberapa siswa mengalami kesulitan sedikit terutama dalam menghubungkan kalimat yakni menggunakan piranti penghubung yang tepat ketika merangkai kalimat yang ada menjadikan paragraf argumentasi yang padu. Ini terjadi jika urutan ide alasan tidak ditata secara beraturan.

Setelah melalui refleksi siklus 1 dengan perubahan dan perbaikan terhadap kelemahan yang ada pada siklus 1 . Pembelajaran menulis argumentasi pada siklus 2 bermediakan gambar sepeda sebagai hadiah yang harus dipilih siswa yaitu sepeda gunung dan sepeda ontel yang antik dan unik. Hampir semua siswa aktif terlibat dalam diskusi untuk berusaha menemukan ide keunggulan atau kelebihan benda yang menjadi pilihannya. Tampak ketua kelompok aktif mencatat temuan idea Jurnal Pendidikan Indonesia | 123 
atau pemikiran anggotanya. Demikian halnya saat diskusi antar kelompok yakni saat penyajian hasil salah satu kelompok yang dianggap terbaik hasil kerjanya ke depan kelas. Semua siswa tampak antusias untuk berpendapat tanpa keraguan, bahkan berebutan sehingga terkesan agak rebut. Sehingga dalam diskusi antar kelompok ini pelaksana tindakan tidak lagi melakukan upaya pemancingan justru tinggal mengendalikan agar diskusi berjalan dengan tertib dan agar tidak terkesan rebut.

Hasil evaluasi terhadap tulisan paragraf argumentasi yang dikerjakan siswa pada siklus 2 diperoleh hasil sebagai berikut. Nilai rata-rata kelas sebesar 83,5 berkategori baik. Siswa yang memperoleh nilai sangat baik sejumlah 16 siswa (53\%), sedangkan siswa yang memperoleh nilai berkategori baik sejumlah 14 siswa (47\%), dan tidak ada siswa yang memperoleh nilai berkategori cukup. Jadi semua siswa telah mencapai target KKM yang ditargetkan sekolah yakni nilai sebesar 70 . Perolehan nilai rata-rata pada siklus II sebesar 83,5 ini telah mengalami peningkatan dibandingkan dengan nilai rata-rata yang dperoleh pada siklus I yakni 75 . Kesalahan yang dilakukan siswa pada siklus I tidak tampak lagi pada siklus II ini.

Siswa sangat antusia dan merespon positif perhadap pelaksanaan pembealajaran Hal ini tampak dari hasil angket dan wawancara adalah sebagai berikut. Semua siswa (100\%) memberikan respon positif terhadap penerapan pembelajaran ini. Adapun alasannya adalah sebagai berikut. Mereka merasa senang karena dapat melihat dalam gambar dengan jelas hadiah yang akan diberikan untuk dipilih dan hadiahnya bagus-bagus yang memang disukainya yakni baik berupa tas sekolah maupun sepeda. Dengan diskusi bersama teman menjadi lebih mudah menemukan hal yang dianggap menarik untuk dijadikan alasan dalam menulis argumentasi. Tambah lebih yakin lagi dengan adanya teman yang tampil ke depan kelas sebagai wakil kelompok yang membantu untuk menemukan alasan dan mengurut alasan yang akan dibuat dalam tulisan. Mereka terasa terbantu dan lebih mudah ketika merangkainya menjadi sebuah paragraf argumentasi. Dengan demikian dapatlah ditegaskan bahwa siswa merespon positif cara pembelajaran menulis argumentasi yang telah diterapkan.

Melalui refleksi atas hasil observasi, skor yang dicapai dalam menulis argumentasi, dan hasil wawancara serta angket, dapatlah disimpulkan bahwa pembelajaran menulis berdasarkan pendekatan konteks dan proses bermediakan gambar dapat meningkatkan kualitas proses dan hasil belajar menulis argumentasi siswa sekolah dasar kelas $\mathrm{V}$ Laboratorium Undiksha.

Meningkatkan mutu pembelajaran merupakan tujuan dilaksanakan pembelajaran untuk mencapai tujuan pembelajaran secara maksimal. Indikator mutu pembelajaran dapat dilihat dari segi proses aktivitas pembelajaran dan dari segi hasil yang dicapai dalam pembelajaran. Gambaran akan lebih lengkap lagi dari pelaksanaan pembelajaran tersebut kalau dilengkapi dengan diketahuinya respon siswa terhadap pembelajaran yang dilaksanakan. Untuk itu, penelitian terhadap masalah tersebut dalam penelitian ini akan memberikan sumbangan yang bermanfaat bagi pelaksaan suatu pembelajaran.

Berdasarkan hasil penelitian ditemukan bahwa penerapan pembelajaran menulis argumentasi berdasarkan pendekatan konteks dan proses 
bermediakan gambar dapat meningkatkan hasil belajar menulis argumentasi siswa SD Lab. Undiksha. Hal ini sudah tentu bisa terjadi. Pada jenjang sekolah dasar saat pembelajaran menulis wacana diperkenalkan, pendekatan konteks sangat cocok dan tepat diterapkan. Dikatakan demikan karena pada jenjang ini, siswa belum bisa diajak berbicara banyak tentang teori menulis. Pemaksaan memperkenalkan istilah-istilah teknis dalam menulis justru akan semakin membingungkan siswa(Sutama, 2010). Sebaliknya, dengan hanya memberikan konteks menulis, terutama tujuan menulis, seperti menceritakan, membedakan atau member pendapat tentang sesuatu, siswa pada jenjang ini akan dapat memproduksi tulisan dengan pola yang sesuai. Leki dkk(2008) menyatakan, "In supprtive, meaning-oriented writing contexts, beginning L2 writers brought with them and were able to draw upon a variety of resources and strategies to succesfully create expresive texts that communicated meaning." Di sisi lain penerapan pendekatan proses pembelajaran menulis terdiri atas beberapa tahap, yaitu: tahap perencanaan,tahap penuangan, dan tahap peninjauan. Aktivitas pramenulis, berdiskusi di dalam kelompok menulis, dan mencoba-coba menulis akan membantu mengembangkan kelancaran menulis, sekaligus mengatasi kemacetan dalam menulis yang diakibatkan oleh keterbatasan memori(Myers dalam Sutama,2010).

Hasil penelitian juga menunjukkan bahwa pembelajaran menulis argumentasi berdasarkan pendekatan konteks dan proses bermediakan gambar dapat meningkatkan aktivitas siswa dalam belajar menulis. Penerapan pendekatan ini dalam pembelajaran menulis adalah siswa dibantu dibimbing melalui tahapan proses menulis yakni mulai dari tahap perencanaan atau pramenulis, tahap penuangan dan tahap peninjauan. Lebih lanjut, siswa dituntut aktif menjalani proses ini dengan harapan mereka dapat menghasilkan tulisan yang baik. Pada tahap perencanaan melalui diskusi kelompok siswa berusaha bertukar pendapat menemukan ide gagasan yang dapat digunakan sebagai alasan atau argumentasi. Melalui pejajian hasil kelompok dan diskusi antar kelompok menuntut siswa untuk aktif baik dalam penambahan ataupun pengurangan ide serta penataan ide yang akan digunakan sebagai bahan menulis argumentasi. Dengan penerapan kedua pendekatan yakni pendekatan konteks dan pendekatan proses hasil pembelajaran dapat ditingkankan juga ativitas siswa dalam belajar dapat ditingkatkan. Dengan mikian mutu pembelajaran menulis argumentasi dapat ditingkatkan. Hasil penelitian sejenis juga mengungkapkan bahwa pembelajaran kontekstual melalui mengobservasi objek otentik dapat meningkatkan mutu pembelajaran menulis (Wendra,2009).

Hasil penelitian juga menunjukkan bahwa siswa merespon positif terhadap pembelajaran menulis argumentasi yang telah diterapkan. Hal ini tentu saja bisa terjadi karena dengan pendekatan proses siswa tidak dijejali dengan teori-teori menulis yang membosankan anak tingkat SD, sedangkan pendekatan proses mengajak siswa mengalami langsung dalam dalam menulis melalui diskusi dengan temannya. Sehingga siswa menjadi senang dalam belajar karena tanpa banyak beban dan tekanan. Lebih-lebih dibantu dengan media gambar yang dekat dengan kehidupan siswa dan disukai siswa. Menurut Piaget(dalam Santyasa dan Sukadi,2008), usia SD yang masih berada pada tahapan Jurnal Pendidikan Indonesia | 125 
operasi konkret sangat memerlukan objekobjek konkret sebagai pijakan untuk memandu belajarnya. Terkait dengan pembelajaran dengan media gambar Wright(1992) mengatakan bahwa gambar dapat memainkan sejumlah peran: (1) Gambar dapat memotivasi murid dan menarik perhatian mereka. (2) Gambar dapat memberikan konteks penggunaan bahasa dan membawa dunia nyata ke dalam kelas. (3) Gambar dapat bercerita sebagaimana adanya, diinterpretasikan, atau dikomentari secara subjektif. (4) Gambar dapat memberikan isyarat tentang jawaban suatu pertanyaan. (5) Gambar dapat memberi stimulus dan informasi untuk diacu dalam bercakap-cakap, berdiskusi dan bercerita. Dengan demikian jelaslah bahwa pembelaran menulis argumentasi sangat efektif dengan penyampaian materi dengan bermediakan gambar sehingga siswa merespon secara positif.

\section{PENUTUP}

Berdasarkan uraian di atas dapat ditarik simpulan sebagai berikut. Penerapan pembelajaran menulis argumentasi berdasarkan pendekatan konteks dan proses bermediakan gambar dapat meningkatkan aktivitas siswa kelas Vb Lab. Undiksha dalam belajar menulis argumentasi. Pembelajaran yang sebelumnya berpusat pada guru yang lebih banyak aktif, setelah penerapan pembelajaran menulis argumentasi berdasarkan pendekatan konteks dan proses bermediakan gambar, pembelajaran jadiberpusat pada siswa dan aktivitas siswa dalam belajar dapat ditingkatkan.

Penerapan pembelajaran menulis argumentasi berdasarkan pendekatan konteks dan proses bermediakan gambar dapat meningkatkan hasil menulis argumentasi siswa kelas Vb Lab. Undiksha. Hasil rata-rata pembelajaran menulis sebelumnya terbatas pada kategori cukup, setelah diterapkan pembelajaran hasil ratarata pembelajaran menulis siswa mencapai kategori baik.

Siswa merespon secara positif terhadap penerapan pembelajaran menulis argumentasi berdasarkan pendekatan konteks dan proses bermediakan gambar karena siswa merasa menjadi lebih mudah dalam menulis dengan adanya penemuan ide yang akan digunakan sebagai dasar berargumentasi sehingga tinggal merangkai menjadi tulisan argumentative. Hal ini menyebabkan pembelajaran menulis dirasakan lebih menyenangkan dan lebih mudah.

Berdasarkan simpulan di atas, dapat disampaikan saran-saran berikut.

Guru pengajar bahasa Indonesia di SD hendaknya menerapkan hasil penelitian ini dalam pembelajaran menulis dengan kemungkinan disesuaikan karakteristik khusus kelas yang dihadapi. Guru dalam memilih topic sebagai bahan yang hendak ditulis hendaknya dipilih bersama siswa, yaitu sesuatu yang dekat dengan kehidupan siswa dan disukai siswa dengan tetap mempertimbangkan tema yang sedang dikembangkan dalam kurikulum. Penelitipeneliti lain hendaknya dapat melakukan penelitian lanjutan di dalam pembelajaran menulis jenis lain, namun pada tingkat kelas atau jenjang yang berbeda

\section{DAFTAR RUJUKAN}

Balitbang, Depdiknas. (2002). Kurikulum Berbasis kompetensi: Kebijakan Umum Pendidikan Dasar dan Menengah Retorika Suatu Pendekatan Terpadu. Jakarta: Depdiknas.

Jurnal Pendidikan Indonesia | 126 
Bormann, Ernest.G. 1991.. Jakarta: Erlangga.

Cohen, Moshe and Riel, Margaret. (1989). The Effect of Distant Audiences on Student Writing. American Educational Research Journal, 26 (2): 143.

Direktorat Jendral Pendidikan Dasar dan Menengah. (2002). Pendekatan Kontekstual (Contextual Teaching Learning). Jakarta:Depdikdasmen.

Dunkin, Michaell J. dan Bruce,J. Biddle. (1974). The Study of Teaching. New York: Holt Rinehart and Winston, Inc.

Gijselaers, W.H. (1996). Connecting Problem Based Learning With Educational Theory, New Direction for Teaching and Learning, 60, 13 - 21.

Keraf, Gorys. 2004. Argumentasi dan Narasi. Jakarta:PT. Gramedia Pustaka Utama.

Leki,Ilona,Cumming,Alister,and

Silva,Tony.2008. A Synthesis of Research on Second Language Writing in English. New York: Routledge.

Read, John A.S. (1991). "The Validity of Writing Test Tasks". In Anivam, Sarinee. Current Development in Language Testing. Singapore: SEAMEO RELC.

Raimes,Ann.1991. Out of the Words: Emerging Traditions in the Teaching of Writing, TESOL Quarterly, 25 (23):407-429.

Sudarsono, F.X. (1996/1997). Pedoman Pelaksanaan Penelitian Tindakan Kelas: Rencana, Desain dan Implementasi. Jakarta: Dirjen Dikti Depdikbud.

Slamet. (2003). Pelaksanaan Pembelajaran Bahasa dan Sastra Indonesia dengan Kurikulum Berbasis Kompetensi(KBK) pada Uji Coba di SMU Negeri 4 Denpasar. IKIP Negeri Singaraja Program Pasca Sarjana(Tesis).

Sutama,Made. 2010. Pembelajaran Menulis yang Memudahkan."Orasi Pengenalan Jabatan Guru Besar
Tetap dalam Bidang Imu Pendidikan Bahasa Indonesia"(tidak diterbitkan)

Sutama, Made.(1998). Pemaduan Pendekatan Konteks, Proses, dan Pola dalam Meningkatkan mutu Pembelajaran Menulis.(Laporan Penelitian).

Toulmin,S. Rieke R. and Janik A. 1979. An Introduction to Reasoning. New York: Macmillan Publishing Co.

Winch, Gordon et al.2006. Literacy: Reading,Writing, and Children Literature. Oxford: Oxford University Press.

Wright,Raumond E. and Rosenberg,seldom.1993."Knowledge of Text Coherence and Expository Writing: A Developmental Study." Journal of Educational Psychology, 1(85):152-158.

Weir, Cyril J. 1990. Communicative Language Testing. New York: Prentice Hall.

Wendra, I. Wayan. 2009.Pembelajaran Kontekstual Melalui Mengobservasi Objek Otentik untuk Meningkatkan Mutu Pembelajaran Menulis Deskripsi Siswa SMPN4 Singaraja." Jurnal IKA(Ikatan Keluarga Alumni) Undiksha." Vol 7 No.1 Februari hal.31-34. 